\title{
KAJIAN KESESUAIAN LAHAN EKOWISATA MANGROVE DIMENSI EKOLOGI (KASUS PADA PULAU BUNAKEN BAGIAN TIMUR, KELURAHAN ALUNG BANUA, KECAMATAN BUNAKEN KEPULAUAN, KOTA MANADO)
}

(Study of the mangrove ecotourism land fitness in ecological dimensions ( case on bunaken the eastern part island, kelurahan continent alung, bunaken sub district island city of manado.)

\author{
Kiki Nadila Bacmid ${ }^{1}$, Joshian N.W. Schaduw ${ }^{1}$, Veibe Warouw ${ }^{1}$, Suria \\ Darwisito ${ }^{1}$, Erly Y. Kaligis ${ }^{1}$, Adnan Wantasen ${ }^{1}$
}

1. Program Studi IImu Kelautan, Fakultas Perikanan dan IImu Kelautan, Universitas Sam

Ratulangi, Manado.

*e-mail : kikinadilabachmid6@gmail.com

Abstract

Ecotourism as a form of tourism that emphasizes responsibility for nature conservation, provides economic benefits and maintains cultural needs for the local community. Mangrove forests with their uniqueness are natural resources that have the potential to be used as tourist attractions. The purpose of this study was to determine community structure, mangrove canopy cover and suitability of mangrove ecotourism land. This study used the line transect method for mangrove community structure, and hemispherical photography for the percentage of mangrove cover. The results of the study of the mangrove community structure were the highest density value, namely at station 1 on the transect 2 types of S.alba 0.16 ind / m2 relative $88.89 \%$ and the lowest density value in the type R. mucronata and R.apiculata 0.01 ind / m2 relatively $5.56 \%$ on transect 2 at station 1 . The highest frequency type value at station 1 on the transect 1 type $\mathrm{S}$. alba which is 1.00 relative $100 \%$ and the lowest frequency at station 1 transect 2 types $\mathrm{R}$, piculate which is relative 0.5033 .33 . The highest closing value of type on transect 2 standard 1 type S. alba 10.26 relative value $92.63 \%$. Whereas the lowest type 3 transect closure is type R. piculate 0.49 the relative is $7.86 \%$. The highest Important Value Index is at station 1 on transect 1, namely type S. alba 300 and lowest at station 1 on transect 2 types $R$. mucronata 30.55. The highest diversity value on transect 2, 0.43 . Evenness index value $(\mathrm{E})$ at station 1 on transect 1 is 0 and transect 2 is 0.39 . While station 2 on transect 10 and transect 20.51 . regarding the criteria for mangrove damage, at 2 stations included in the rare category with inya $50 \%$ canopy cover. The overall results of land suitability for coastal tourism in the Bunaken Island mangrove tourism category fall into the very appropriate category.

Keywords: Mangrove, Ecotourism, Bunaken Island

\section{Abstrak}

Ekowisata sebagai suatu bentuk wisata yang menekankan tanggung jawab terhadap kelestarian alam, memberikan manfaat secara ekonomi dan mempertahankan kebutuhan budaya bagi masyarakat setempat. Hutan mangrove dengan keunikan yang dimilikinya, merupakan sumberdaya alam yang sangat berpotensi untuk dijadikan sebagai tempat kunjungan wisata. Tujuan dari penelitian ini adalah untuk mengetahui struktur komunitas, tutupan kanopi mangrove dan kesesuaian lahan ekowisata mangrove. Penelitian ini menggunakan metode line transek terhadap struktur komunitas mangrove, dan hemispherical photography untuk persentase tutupan mangrove. Hasil penelitian struktur komonitas mangrove yaitu Nilai kerapatan tertinggi yaitu pada stasiun 1 di transek 2 jenis S.alba 0.16 ind/m2 relatifnya $88.89 \%$ dan nilai kerapatan terendah pada jenis $R$. mucronata dan R.apiculata $0.01 \mathrm{ind} / \mathrm{m} 2$ relatifnya $5.56 \%$ di transek 2 pada stasiun 1 .Nilai frekuensi jenis tertinggi pada stasiun 1 di transek 1 jenis S.alba yaitu 1.00 relatifnya $100 \%$ dan frekuensi terendah pada stasiun 1 transek 2 jenis $R$, piculate yaitu 0.50 relatifnya 33.33. Nilai 
penutupan jenis tertinggi pada transek 2 stasun 1 jenis S. alba 10.26 nilai relatifnya $92.63 \%$. Sedangkan penutupan jenis terendah transek 3 jenisR. piculate 0.49 relatifnya $7.86 \%$. Indeks Nilai Penting tertinggi yaitu pada stasiun 1 di transek 1 yaitu jenis S.alba 300 dan terendah pada stasiun 1 di transek 2 jenis R.mucronata 30.55.Nilai keanekaragaman tertinggi pada transek 2, 0.43. Nilai indeks kemerataan (E) pada stasiun 1 di transek 1 yaitu 0 dan transek 2 0,39 . Sedangkan stasiun 2 pada transek 10 dan transek 20.51 . tentang kriteria kerusakan mangrove, pada ke 2 stasiun termasuk pada kategori jarang dengan tutupan kanopinya $\leq 50 \%$

. Hasil keseluruhan kesesuaian lahan untuk wisata pantai kategori wisata mangrove Pulau Bunaken masuk pada kategori sangat sesuai.

Kata kunci: Mangrove, Ekowisata, Pulau Bunaken

\section{PENDAHULUAN}

Hutan mangrove adalah tipe hutan yang khas terdapat di sepanjang pantai atau muara sungai yang dipengaruhi oleh pasang surut air laut. Mangrove tumbuh pada pantai yang terlindung atau pantai yang datar, biasanya di sepanjang sisi pulau yang terlindung dari angin atau di belakang terumbu karang di lepas pantai yang terlindung (Nybakken, 1992). Mangrove juga merupakan kelompok tumbuhan yang dapat tumbuh dengan baik pada kawasan pasang surut di daerah tropis dan subtropis (LIPI, 2014) dan mampu beradaptasi dengan lingkungan yang ekstrim baik suhu yang tinggi, sedimentasi tinggi, salinitas tinggi, pasang surut ekstrim, serta substrat yang kaya oksigen dan tanpa oksigen (Dharmawan dan Pramudji, 2014). Secara ekologis mangrove memiliki fungsi yang sangat penting dalam memainkan peranan sebagai mata rantai makanan di suatu perairan, yang dapat menumpang kehidupan berbagai jenis ikan, udang dan moluska. Ekosistem mangrove selain berfungsi ekologis bagi sektor perikanan juga berfungsi sebagai pelindung garis pantai, mencegah abrasi air laut, habitat aneka biota perairan, serta sebagai pengatur iklim mikro. Manfaat penting lain ekosistem mangrove adalah mampu menyerap karbon dioksida (CO2 ) dari udara (Murdiyarso, 2015).

Pembangunan wilayah pesisir dan laut secara berkelanjutan merupakan kebijakan penting Departemen Kelautan dan Perikanan. Kebijakan tersebut didasarkan pada pemikiran bahwa wilayah pesisir dan laut secara ekologis dan ekonomis potensial untuk dikembangkan dan dimanfaatkan untuk kesejahteraan masyarakat. Meskipun pemerintah telah melakukan berbagai upaya untuk mendorong pemanfaatan sumberdaya pesisir dan laut secara berkelanjutan, pola pemanfaatan yang sifatnya merusak dan mengancam kelestarian sumberdaya pesisir dan laut masih saja terus berlangsung. Hal ini disebabkan oleh desakan kebutuhan hidup, yang semakin lama semakin tinggi. Pengembangan ekonomi wisata (ekowisata) merupakan salah satu alternatif pembangunan yang dapat membantu mengatasi masalah tersebut. Pemanfaatan ekosistem mangrove untuk konsep wisata (ekowisata) sejalan dengan pergeseran minat wisatawan dari old tourism yaitu wisatawan yang hanya datang melakukan wisata saja tanpa ada unsur pendidikan dan konservasi menjadi new tourism yaitu wisatawan yang datang untuk melakukan wisata yang di dalamnya ada unsur pendidikan dan konservasi (Tuwo, 2011). Seiring dengan pertumbuhan penduduk yang semakin cepat, maka kebutuhan hidup manusia akan semakin meningkat. Dengan meningkatnya kebutuhan ini akan menimbulkan tekanan terhadap sumberdaya alam, dimana pemanfaatan belum banyak memperhitungkan kerugian yang berdampak ekologis. Demikian juga dengan pembangunan wilayah pesisir sekitar kawasan hutan mangrove, pemanfaatan wilayahnya biasanya tidak dilakukan dengan bijaksana dan berwawasan lingkungan (Muhaerin, 2008). 
Luas hutan mangrove pada PPK Taman Nasional Bunaken (TNB) sebesar 977.63 ha khusunya di Pulau Bunaken ( \pm 7,5 Ha), luas total hutan mangrove di TNB termaksud yang tua di Asia Tenggara. Indikasinya masi ditemukan mangrove yang berukuran beasar dengan diameter di atas $1.5 \mathrm{~m}$ yang pada tempat lain sudah jarang ditemukan. (BTNB, 2010). Pengembangan kegiatan ekowisata akan diterapkan sebagai salah satu pendekatan untuk mengatasi permasalahan lingkungan. Pengembangan kegiatan ekowisata juga dapat menekan tingkat eksploitasi yang berlebihan oleh masyarakat sekitar kawasan dengan menciptakan alternatif ekonomi, khususnya bagi masyarakat di pesisir.terumbu karang yang baik sehingga tidak diragukan lagi wilayah ini memiliki keanekaragaman organisme laut.
Namun sayang sekali bahwa usaha yang dilakukan untuk mengeksplorasi dan mengeksploitasi bahan-bahan aktif dari biota laut tersebut masih sangat sedikit. Dengan demikian perlu dilakukan penelitian mengenai biota laut khususnya ascidian dalam upaya pemanfaatan senyawa bioaktif yang nantinya dapat dijadikan bahan baku pembuat bahan farmasi.

\section{Waktu dan Tempat Penelitian}

Penelitian ini dilakukan di Pulau Bunaken bagian Barat, Kecamatan Bunaken, Kota Manado, Provinsi Sulawesi Utara . Waktu yang digunakan untuk penelitian ini selama 3 bulan, mulai dari konsultasi, penulisan proposal dan pelaksanaan penelitian (April - Juni 2019).

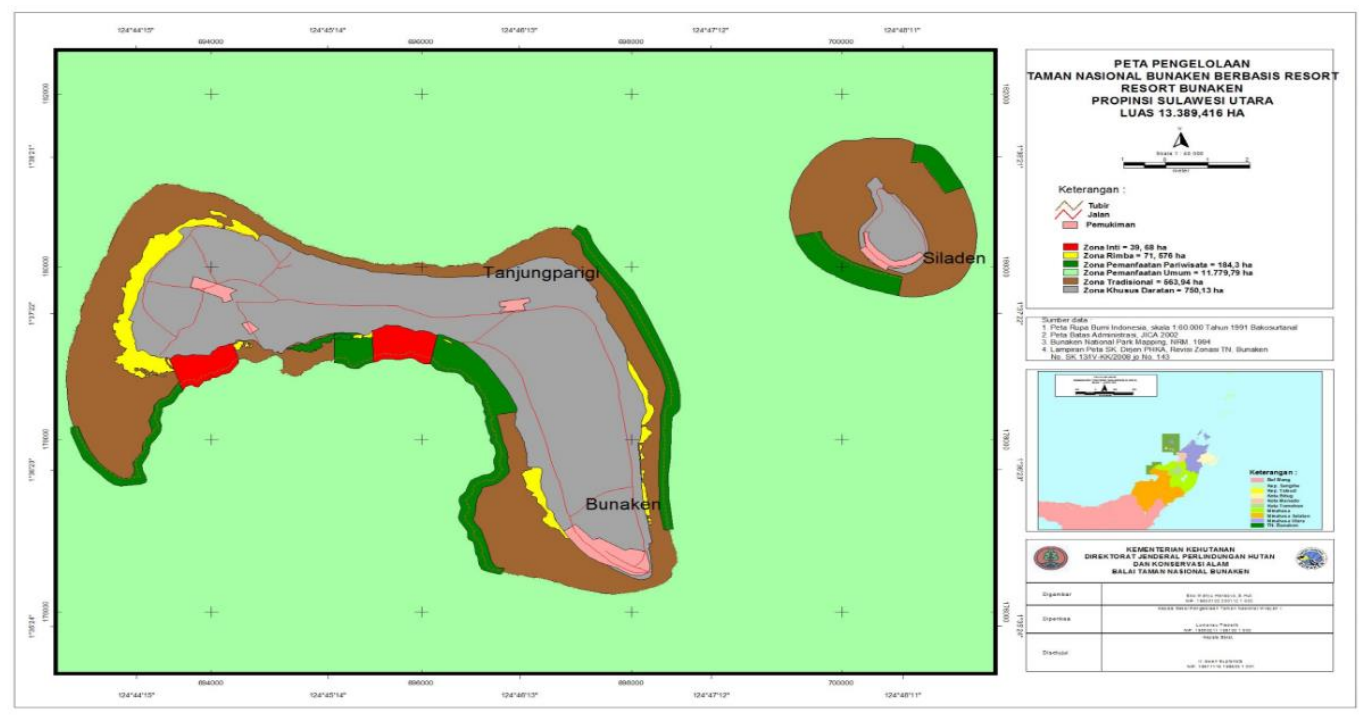

Gambar 1. Peta Pengambilan Sampel 


\section{METODE PENELITIAN}

\section{Alat dan Bahan}

Penelitian ini membutuhkan bahan dan alat yang menunjang agar kegiatan penelitian dapat berjalan dengan baik dengan hasil yang memuaskan. Adapun alat dan bahan yang digunakan dalam penelitian ini (Tabel 1.) yaitu sebagai berikut : Meteran jahit (150 m), tali Rafia, GPS (Global Positioning System), meteran rol $(50 \mathrm{~m})$, kamera handphone, alat Tulis.

\section{Metode Penelitian}

Metode yang digunakan dalam kegiatan penelitian ini adalah metode survey lapangan, yaitu pengamatan secara langsung di lapangan terhadap kondisi ekosistem mangrove. Pengamatan dan pengukuran di lapangan untuk mengetahui struktur komunitas mangrove dan kesesuaian lahan ekowisata mangrove yaitu dengan menggunakan metode line transect. Serta pengambilan gambar dalam mengetahui persentase tutupan mangrove dengan menggunakan metode hemisperichal photography.

Metode line transect dilakukan dengan cara membuat garis tegak lurus pantai ke arah darat dengan membuat petakan atau plot 10x10 m (Cox, 1969 dalam Abrar dkk., 2014). Selanjutnya, metode hemisperichal photography adalah teknik untuk mengetahui persentase tutupan kanopi mangrove dengan menggunakan foto-foto dalam memperkirakan radiasi matahari dan ciri tanaman melalui lensa pandang jauh (Anderson, 1964).

\section{Prosedur Penelitian}

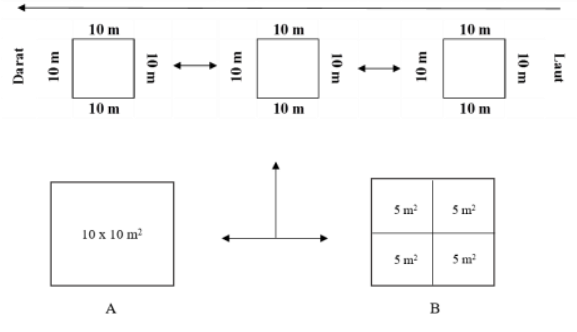

Gambar 2. Skema penempatan petak contoh/plot
Penelitian dilakukan pada 2 stasiun. Tiap stasiun terdapat 2 line transek dan pada setiap transek terdapat 3 petak/plot pengambilan data. Jalur transek pengamatan dimulai dengan arah tegak lurus dari arah laut ke arah darat (Gambar 2) sepanjang adanya mangrove, dimana jalur transek yang akan dibuat harus mewakili wilayah penelitian dan harus mewakili setiap zonasi hutan mangrove yang ada.

Keterangan :

A : Petak pengukuran untuk pohon (10x10 m2) dengan menggunakan metode line transect.

B : Petak pengambilan gambar/fotofoto $(5 \times 5 \mathrm{~m} 2)$ dengan

menggunakan metode hemisperichal photography.

\section{Persentase Tutupan Mangrove}

Persentase tutupan mangrove di hitung dengan menggunakan metode hemisperichal photography (Gambar 3). Teknik ini masih cukup baru digunakan di Indonesia pada hutan mangrove, keuntungan dari penggunaan metode photography adalah penelitian yang lebih mudah, bersifat lebih akurat dan adanya bukti yang kuat (Dharmawan dan Pramudji, 2014). Sedangkan kelemahannya tidak dapat dilakukan pada semua jenis pohon mangrove, air pasang, hujan, dan pengambilan gambar hanya dilakukan oleh satu orang.

Untuk prosedur pengambilan gambar dalam persentase tutupan mangrove dengan menggunakan metode hemisperichal photography yaitu (Dharmawan dan Pramudji, 2014) :

1. Setiap plot yang berukuran $10 \times 10$ m2 dibagi kembali menjadi empat plot kecil dengan ukuran 5×5 m2 (Gambar 2).

2. Pengambilan foto (kamera handphone) harus menyesuaikan keberadaan pohon di dalam plot dan titik pengambilannya berada diantara satu pohon dengan pohon lainnya (Gambar 3).

3. Posisi kamera disejajarkan dengan tinggi dada peneliti, serta tegak lurus menghadap ke langit.

4. Pengambilan foto sebanyak 12 titik dimana setiap plot $10 \times 10 \mathrm{~m} 2$ diambil 4 titik pemotretan. 
5. Hindarkan pengambilan foto ganda/berulang-ulang untuk mencegah kebingungan pada saat analisis.
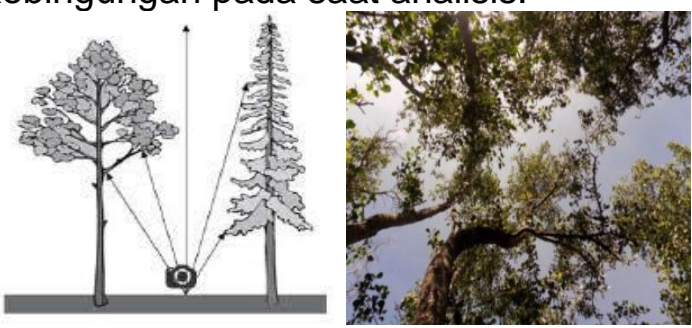

Gambar. 3

(a) Ilustrasi metode hemisperichal photography dalam pengambilan foto (Jenning et al., 1999; Korhonen et al., 2006) (b) Contoh hasiln foto yang dipotret.

Pengukuran Struktur Komunitas Mangrove Pengukuran struktur komunitas mangrove di lapangan dengan menggunakan metode line transect yaitu (Dharmawan dan Pramudji, 2014) :

1.Dalam setiap plot $10 \times 10 \mathrm{~m} 2$ dilakukan pengukuran diameter batang pohon mangrove ( keliling batang ), pengukuran dilakukan dengan menggunakan meteran pada seluruh pohon yang berada di dalam plot.

2.Mengidentifikasi setiap jenis pohon yang berada di setiap plot berdasarkan acuan Noor dkk., (2012). Jika terjadi keraguan dalam identifikasi, maka dapat dilakukan pemotretan bahkan mengambil bagian tanaman yaitu akar, batang, daun, bunga dan buah untuk diidentifikasi lebih lanjut di laboratorium atau dengan bantuan literatur lainnya

3.Dicatat setiap data yang diperoleh untuk masuk kedalam tahap analisisnya.
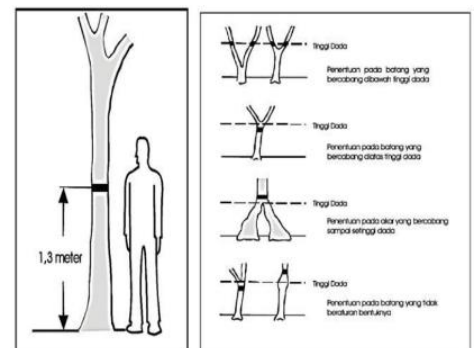

Gambar. 4 llustrasi posisi pengukuran lingkar batang pohon mangrove berdasarkan pada Keputusan Menteri Lingkungan Hidup RI No. 201 tahun 2004 entang Kriteria Baku dan Pedoman Penentuan Kerusakan Mangrove. erlenmeyer $250 \mathrm{ml}$ juga. Kedua fraksi ini dievaporasi dan kemudian akan diambil menggunakan spatula dan dipindahkan ke botol sampel kecil bersamaan dengan fraksi air yang sudah dievaporasi terlebih dahulu. Selanjutnya ketiga fraksi ditimbang menggunakan timbangan analitik.

\section{Analisis Data}

\section{Analisis Persentase Tutupan Mangrove}

Dalam metode hemisperichal photography, ImageJ merupakan aplikasi yang digunakan untuk menganalisis foto hasil pemotretan. Konsep dalam analisis ini adalah untuk memisahkan pixel langit dan tutupan mangove. Aplikasi ini sangat berguna dalam pengolahan citra (Gambar 5).

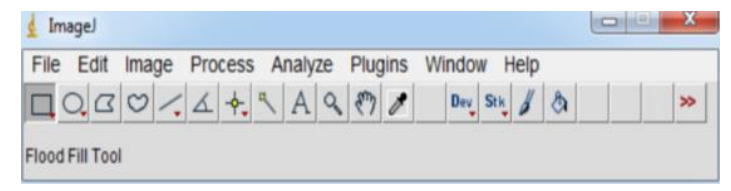

Gambar. 5 Tampilan utama aplikasi ImageJ (Dharmawan dan Pramudji, 2014)

Adapun tahapan dalam mengolah foto pada aplikasi ImageJ yaitu (Dharmawan dan Pramudji, 2014) :

-Membuka aplikasi ImageJ

-Pada ImageJ, buka gambar/foto pada tempat penyimpanan. File >> Open... >> [pilih foto]

-Ubah foto menjadi 8-bit

Image >> Type >> 8-bit

- Pisahkan langit dan tutupan mangrove Image >> Adjust >> Threshold

-Pada kotak Threshold, pisahkan nilai digital pixel langit dan tutupan vegetasi secara signifikan dengan cara menyesuaikan scrool kedua (ke kiri atau kanan) sampai memperoleh komposisi cahaya untuk memperoleh akurasi ratio dua tipe digital pixel yang lebih tepat, kemudian tekan Apply (Default : B/W).

- Dihitung banyaknya pixel yang bernilai 255 sebagai intepretasi tutupan mangrove.

Analyze >> Histogram 
Perhitungan persentase tutupan mangrove dalam aplikasi ImageJ yaitu dengan cara :

Dimana :

P255 = Jumlah pixel yang bernilai 255

$\mathrm{SP}=$ Jumlah seluruh pixelpemakaian.

Setelah itu masing-masing erlenmeyer ditutup dengan alumunium foil dan diinkubasi selama $1 \times 24$ jam pada suhu ruang.

Interpretasi
Status
Hutan Mangrove
Untuk data hasil analisis persentase tutupan mangrove digunakan untuk menggambarkan status kerusakan hutan mangrove yang dikategorikan menjadi tiga, yaitu jarang, sedang dan sangat padat berdasarkan standar baku kerusakan hutan mangrove berdasarkan Keputusan Menteri Lingkungan Hidup No. 201 tahun 2004 (Tabel 2).

Tabel 2. Kriteria kerusakan hutan mangrove berdasarkan Keputusan Menteri Lingkungan Hidup No. 201 tahun 2004.

\section{Kriteria Penutupan}

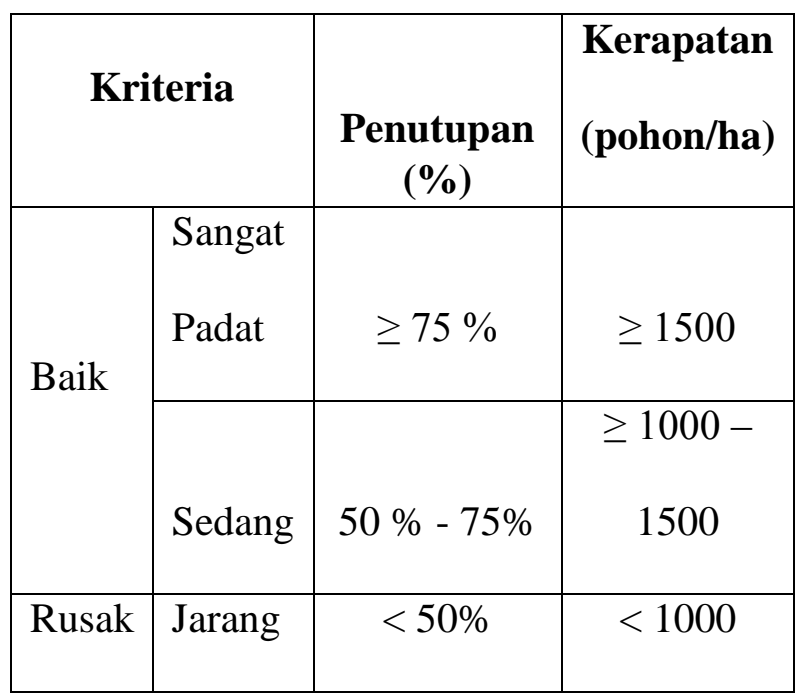

\section{Analisis Struktur Komunitas Mangrove \& Kesesuaian Ekologis}

\section{Struktur Komunitas Mangrove}

Dalam mengetahui gambaran struktur komunitas mangrove, data dapat diolah dan dianalisa dengan cara menghitung nilai-nilai kerapatan jenis, kerapatan relatif jenis, frekuensi jenis, frekuensi relatif jenis, penutupan jenis, penutupan relatif jenis, indeks nilai penting, indeks keanekaragaman jenis, indeks kemerataan jenis (Odum, 1971) sebagai berikut :

a) Kerapatan jenis (Di) Jumlah Total Individu Spesies

b) Kerapatan Relatif Jenis (RDi) $R D i=$

c) Frekuensi Jenis $(\mathrm{Fi}) \mathrm{Fi}=$

d) Frekuensi Relatif Jenis (RFi) $R F i=$

d) Penutupan Jenis ( $\mathrm{Ci}) \mathrm{Ci}=$

f) Penutupan Relatif Jenis ( $\mathrm{RCi}) \mathrm{RCi}=$

g) Dari hasil perhitungan rumus diatas kemudian dihitung indeks nilai penting (INP) dengan menggunakan rumus INP $=R D i+R F i+R c i h)$.

$\left(\mathrm{H}^{\prime}\right) \quad$ Keanekaragaman jenis adalah parameter yang sangat berguna untuk membandingkan dua komunitas, terutama untuk mempelajari pengaruh gangguan biotik, untuk mengetahui tingkatan suksesi atau kestabilan suatu komunitas. Keanekaragaman ditentukan dengan Pengamatan dan Pengukuran.

$$
\mathrm{H}^{\prime}=-\sum_{i=1}^{\mathrm{n}}\left(\frac{\mathrm{ni}}{\mathrm{N}} \ln \frac{\mathrm{ni}}{\mathrm{N}}\right)
$$

\section{Kesesuaian Ekologis}

Kegiatan wisata yang akan dikembangkan hendaknya disesuaikan dengan potensi sumberdaya. Setiap kegiatan wisata mempunyai persyaratan sumberdaya dan lingkungan yang sesuai objek wisata yang akan dikembangkan. Rumus yang digunakan untuk kesesuaian wisata pantai dan wisata bahari adalah (Yulianda, 2007):

Dimana :

$\mathrm{IKW}=\Sigma \mathrm{Ni} / \mathrm{nmax}$ 
$\mathrm{IKW}=$ Indeks kesesuaian ekosistem untuk wisata mangrove

$\mathrm{Ni}=$ Nilai parameter ke-i (Bobot $\mathrm{x}$ Skor)

Untuk penentuan kesesuaian berdasarkan perkalian skor dan bobot yang diperoleh dari setiap parameter. Kesesuaian kawasan dilihat dari jumlah yang paling tinggi yang diperoleh dari seluruh parameter. Berdasarkan Tabel 3. Kesesuaian wisata pantai kategori wisata mangrove mempertimbangkan 8 parameter dengan 4 klasifikasi penilaian.

Parameter kesesuaian wisata pantai kategori wisata mangrove antara lain: Tutupan kanopi, kerapatan mangrove, jenis mangrove, pasang surut.

Matriks kesesuaian lahan untuk wisata pantai kategori wisata mangrove

No Parameter Bobot Kategori baik Skor Kategori cukup baik Skor Kategori cukup buruk Skor Kategori Buruk Sko

\section{Tutupan Kanopi}

Tutupan Kanopi dilakukan dengan pengambilan foto diantara satu pohon dengan pohon lainnya yang ada disetiap plot $10 \times 10 \mathrm{~m} 2$ yang telah dibagi 4 titik berukuran $5 \times 5 \mathrm{~m} 2$. Data tutupan kanopi diolah untuk mengetahui presentase tutupan kanopi menggunakan metode hemispherical photography.

\section{Kerapatan Mangrove}

Dilakukan dengan metode line transect kuadrat menarik tali sepanjang $100 \mathrm{~m}$ dengan plot berukuran $10 \times 10 \mathrm{~m} 2$.

\section{Jenis Mangrove}

Dilakukan dengan metode line transect serta mengamati jenis - jenis di setiap plot.

\section{Pasang Surut}

Diambil dari data sekunder yaitu dokumen data pasang surut.

\begin{tabular}{|c|c|c|c|c|c|c|c|c|c|c|}
\hline $\begin{array}{c}\text { N } \\
\mathbf{0}\end{array}$ & Parameter & $\begin{array}{c}\text { B } \\
\mathbf{0} \\
\mathbf{b} \\
\mathbf{0 t}\end{array}$ & $\begin{array}{c}\text { Kategori } \\
\text { baik }\end{array}$ & Skor & $\begin{array}{c}\text { Kategori } \\
\text { cukup } \\
\text { baik }\end{array}$ & Skor & $\begin{array}{c}\text { Kategori } \\
\text { cukup } \\
\text { buruk }\end{array}$ & Skor & $\begin{array}{c}\text { Kategori } \\
\text { Buruk }\end{array}$ & Skor \\
\hline 1. & $\begin{array}{c}\text { Tutupan } \\
\text { Kanopi (m) }\end{array}$ & 5 & $>75 \%$ & 3 & $>50-74.9 \%$ & 2 & $5-24.9 \%$ & 1 & $<5$ & 0 \\
\hline $\begin{array}{c}\text { Kerapatan } \\
\text { Mangrove } \\
(100 \mathrm{~m})\end{array}$ & 3 & $15-25$ & 3 & $10-15$ & 2 & $5-10$ & 1 & $<5$ & 0 \\
\hline 3. & $\begin{array}{c}\text { Jenis } \\
\text { Mangrove }\end{array}$ & 3 & $>5$ & 3 & $3-5$ & 2 & $1-2$ & 1 & 0 & 0 \\
\hline 4. & $\begin{array}{c}\text { Pasang } \\
\text { Surut (m) }\end{array}$ & 1 & $0-1$ & 3 & $>1-2$ & 2 & $>2-5$ & 1 & $>5$ & 0 \\
\hline
\end{tabular}

Keterangan Kesesuaian :

Sangat Sesuai $\quad: 70-100 \%$

Sesuai : $52-77 \%$

Sesuai Bersyarat : $26-51 \%$

Belum Sesuai : $:<26 \%$
HASIL DAN PEMBAHASAN

\section{Hasil Analisis Struktur Komunitas Mangrove \\ Kerapatan jenis dan Kerapatan relatif jenis}

Kerapatan jenis mangrove adalah jumlah tegakan jenis per individu dalam suatu area sedangkan kerapatan relatif jenis mangrove adalah perbandingan antara jumlah tegakkan individu/jenis 
dengan jumlah total tegakkan seluruh jenis (Bengen, 2003). Pada stasiun 1 kerapatan jenis mangrove di transek 1 jenis Sonneratia alba 0,14 ind/m2 dengan kerapatan relatif $100 \%$, transek 2 S. alba $0.16 \mathrm{ind} / \mathrm{m} 2$ relatifnya $88.89 \%$, R.mucronata $0.01 \mathrm{ind} / \mathrm{m} 2$ relatifnya 5.56 $\%$, dan R.apiculata $0.01 \mathrm{ind} / \mathrm{m} 2$ relatifnya $5.56 \%$. Sedangkan pada stasiun 2 di transek 1 jenis $\mathrm{S}$. alba memiliki kerapatan jenis $0.09 \mathrm{ind} / \mathrm{m} 2$ dengan kerapatan relatif $56.67 \%$, R.mucronata 0.04 ind $/ \mathrm{m} 2$ relatifnya $23.33 \%$, dan R.apiculata 0.03 ind $/ \mathrm{m} 2$ relatifnya $20 \%$. Pada Transek 2 jenis S. alba 0.03 ind $/ \mathrm{m} 2$ relatifnya $16.22 \%$ dan R.apiculata 0.16 ind $/ \mathrm{m} 2$ relatifnya $83.78 \%$. Nilai kerapatan tertinggi yaitu pada stasiun 1 di transek 2 jenis S.alba $0.16 \mathrm{ind} / \mathrm{m} 2$ relatifnya $88.89 \%$ dan nilai kerapatan terendah pada jenis $R$. mucronata dan R.apiculata $0.01 \mathrm{ind} / \mathrm{m} 2$ relatifnya $5.56 \%$ di transek 2 pada stasiun 1.Tingginya nilai kerapatan jenis ditentukan oleh banyaknya jumlah individu, begitu pula sebaliknya jika jumlah individunya sedikit maka nilai kerapatannya rendah. Kerapatan jenis tertinggi disebabkan oleh subsrat yang cocok, dan kemampuan beradaptasi dengan kondisi lingkungan. Faktor yang menyebabkan pertumbuhan mangrove relatif jarang adalah kondisi akar pohon yang tergolong besar sehingga pertumbuhan mangrove tersebut menjadi kurang optimal (Agustini dkk., 2016). Semakin rapat suatu ekosistem mangrove akan semakin baik dalam hal mereduksi gelombang dan menahan sedimen ataupun sampah dari daratan, akan tetapi hal ini juga akan berdampak buruk bagi pertumbuhan dan regenerasi mangrove. Minimnya penyinaran matahari akan memperlambat proses fotosintesis yang membuat semai ataupun tumbuhan pacang sulit untuk berkembang (Schaduw, 2016).

\section{Frekuensi jenis dan Frekuensi relatif jenis}

Frekuensi jenis adalah peluang ditemukannya jenis ke i dalam petak contoh/plot yang diamati sedangkan frekuensi relatif jenis adalah perbandingan antara frekuensi jenis ke $\mathrm{i}$ dan jumlah frekuensi untuk seluruh jenis (Bengen,
2003). Dari hasil penelitian didapat bahwa frekuensi jenis dan frekuensi relatif jenis (Tabel 6 dan 7) pada stasiun 1 di transek 1 jenis S.alba 1.00 dengan frekuensi relatifnya $100 \%$, transek 2 jenis S.alba 1.00 relatifnya $40 \%$, R.mucronata 0.50 relatifnya $20 \%$ dan R.apiculata 1.00 relatifnya $40 \%$. Sedangkan pada stasiun 2 transek 1 jenis S.alba 1.00 relatifnya $33.33 \%$, R.mucronata 1 relatifnya $33.33 \%$ dan R.apiculata 1.00 relatifnya $33.33 \%$. Transek 2 Jenis S.alba 0.50 relatifnya $33.33 \% \quad$ R.apiculata 1.00 relatifnya $66.67 \%$. Nilai frekuensi jenis tertinggi pada stasiun 1 di transek 1 jenis S.alba yaitu 1.00 relatifnya $100 \%$ dan frekuensi terendah pada stasiun 1 transek 2 jenis $R$, piculate yaitu 0.50 relatifnya 33.33 .

Secara keseluruhan jenis s.alba ditemukan pada setiap plot/petak pengamatan. Hal ini menunjukan bahwa jenis ini memiliki penyebaran jenis dan keberadaan yang lebih tinggi jika dibandingkan dengan jenis yang lainnya. Menurut Poedjirahajoe, 1966 dalam Rusydi, dkk 2015 substrat jenis lempung berpasir atau berlumpur memang merupakan substrat yang sangat cocok untuk tempat tumbuhnya jenis R.apiculata. Juga menurut Arief, 2003 dalam Rusydi, dkk 2015 mengatakan substrat adalah tempat dimana akar-akar mangrove dapat tumbuh. Karakteristik substrat yang baik menentukan banyaknya tegakan mangrove yang dapat tumbuh dan berkembang.

\section{Penutupan jenis dan Penutupan relatif jenis}

Nilai penutupan jenis yang di dapat dari hasil penelitian yaitu pada stasiun 1 di transek 1 jenis $S$. alba memiliki penutupan jenis 0,21 relatifnya $100 \%$, transek 2 jenis S,alba 10.26 relatifnya $92.63 \%, \mathrm{R}$, piculate 0.55 relatifnya $5 \%$ dan R.apiculata 0.26 relatifnya $2.37 \%$. Sedangkan stasiun 2 pada transek 1 jenis S, alba 7.71 relatifnya $83.01 \%$, $\mathrm{R}$, piculate 0.85 relatifnya $9.13 \%$ dan $\mathrm{R}$.apiculata 0.73 relatifnya $7.86 \%$. Transek 2 jenis. S,alba 3.51 relatifnya $46.26 \%$ R.apiculata 4.11 relatifnya $53.74 \%$. Nilai penutupan jenis tertinggi pada transek 2 stasun 1 jenis S. alba 10.26 nilai relatifnya $92.63 \%$. 
Sedangkan penutupan jenis terendah transek 3 jenisR. piculate 0.49 relatifnya $7.86 \%$.

Sofian dkk., (2012) menyatakan bahwa kondisi hutan mangrove yang berhadapan langsung dengan laut sehingga mendapatkan pasang surut air laut sangat mendukung jenis tersebut untuk tumbuh. Selanjutnya Faktor yang mempengaruhi rendahnya nilai penutupan jenis karena adanya kondisi mangrove yang heterogen. Menurut Raymond dkk., (2010), semakin heterogen jenis mangrove dalam suatu komunitas maka peranannya terbagi-bagi dan besarnya indeks semakin bervariasi.

\section{Indeks Nilai Penting}

Indeks Nilai Penting (INP) mangrove yang didapat yaitu pada stasiun 1 di transek 1 S.alba memiliki Indeks Nilai Penting 300, transek 2 S.alba 221.52, R.mucronata 30.55 dan R.apiculata 47.93. Sedangkan stasiun 2 pada transek 1 S.alba 173.01, R.mucronata 65.80 dan R.apiculata 61.19, transek 2 S.alba 95.81 R.apiculata 204.19. Indeks Nilai Penting tertinggi yaitu pada stasiun 1 di transek 1 yaitu jenis S.alba 300 dan terendah pada stasiun 1 di transek 2 jenis R.mucronata 30.55.

Dari keseluruhan transek pada tiap stasiun hanya 1 jenis mangrove yang memiliki INP tertinggi dan tersebar di semua transek yaitu jenis Sonneratia Alba, jenis ini memiliki peran cukup penting dalam lingkungan Pulau Bunaken. Menurut Indriyanto (2006), bahwa spesies-spesies yang dominan dalam suatu komunitas tumbuhan memiliki indeks nilai penting yang tinggi, sehingga spesies yang paling dominan memiliki indeks nilai penting yang paling besar. Selanjutnya Raymond dkk., (2010) menambahkan bahwa jenis yang memperoleh INP tinggi berarti mempunyai nilai kumulatif penguasaan yang lebih besar dan lebih menguasai habitatnya. Jenis ini lebih unggul dalam memanfaatkan sumberdaya atau lebih dapat menyesuaikan diri dengan lingkungan setempat.

\section{Indeks keanekaragaman Jenis dan Indeks kemerataan jenis}

Nilai indeks keanekaragaman jenis $\left(H^{\prime}\right)$ pada stasiun 1 di transek 1 yaitu 0 dan transek 2 0.43. Sedangkan stasiun 2 pada transek 1 yaitu 0 dan transek 2 0.36. Nilai keanekaragaman tertinggi pada transek 2, 0.43. Nilai indeks kemerataan (E) pada stasiun 1 di transek 1 yaitu 0 dan transek 2 0,39. Sedangkan stasiun 2 pada transek 10 dan transek 20.51 .

Dahuri 2003 dalam Bessie dkk., 2013 menyatakan bahwa keanekaragaman ekosistem mangrove terbentuk karena pola zonasi di mana pola ini berkaitan erat dengan faktor lingkungan, seperti tanah (lumpur, pasir, dan gambut), keterbukaan terhadap hempasan gelombang, salinitas, dan pengaruh pasang surut. Selanjutnya, menurut Indriyanto 2006 dalam Anthoni dkk., 2017, keanekaragaman spesies juga dapat digunakan untuk mengukur stabilitas komunitas, yaitu kemampuan suatu komunitas untuk menjaga dirinya tetap stabil.

\section{Kesesuaian Ekologis Tutupan Mangrove}

Berdasarkan hasil analisis tutupan kanopi mangrove yang dilakukan dengan metode hemispherical photography di Pulau Bunaken, yang ditinjau dari Kepmen LH No.201 Tahun 2004 tentang kriteria kerusakan mangrove tutupan kanopi mangrove pada ke 2 stasiun berbeda. Pada stasiun 1 di transek 1 memiliki nilai tutupan kanopi mangrove (34.46\%). Transek 2 dengan nilai (47.54 $\%)$. Sedangkan pada stasiun 2 transek 1 memiliki nilai tutupan kanopi (15.73\%) dan transek 2 (33.73). Ditinjau dari Kepmen LH No. 201 Tahun 2004 tentang kriteria kerusakan mangrove, pada ke 2 stasiun termasuk pada kategori jarang dengan tutupan kanopinya $\leq 50 \%$.

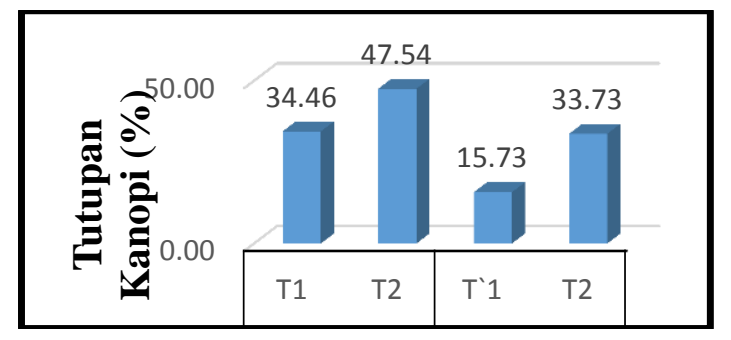


Gambar 6. Histogram persentase tutupan kanopi

Berdasarkan matriks kesesuaian lahan untuk wisata pantai kategori wisata mangrove, tutupan mangrove pada stasiun 1 di transek 1 masuk pada kategori cukup baik yaitu $34.46 \%$ dengan skor 2 dan bobot 5 . Transek 2 masuk pada kategori cukup baik $47.54 \%$ dengan skor 2 dan bobot 5 . Sedangkan pada stasiun 2 di transek 1 masuk pada kategori cukup buruk $15.73 \%$ dengan skor 1 dan bobot 5 . Transek 2 masuk pada kategori cukup baik $33.73 \%$ dengan skor 3 dan bobot 5 .

\section{Kerapatan Mangrove}

Kerapatan mangrove dalam setiap stasiun yang terdiri dari 2 transek dengan 2 plot. Pada stasiun 1 di transek 1 (14 ind/ha) berdasarkan matriks kesesuaian lahan wisata mangrove masuk ke kategori baik. Pada transek 2 kerapatannya (6 ind/ha) berdasarkan matriks kesesuaian lahan wisata mangrove masuk cukup buruk Sedangkan pada stasiun 2 di transek 1 kerapatannya (5 ind/ha) berdasarkan matriks kesesuaian lahan wisata mangrove maka masuk ke kategori cukup buruk. Transek 2 kerapatannya (9 ind/ha) berdasarkan matriks kesesuaian lahan wisata mangrove masuk ke kategori cukup buruk. Kerapatan vegetasi mangrove yang tinggi menunjukkan bahwa komunitas vegetasi tersebut berada pada kondisi yang tidak mengalami gangguan (Erwin, 2005 dalam Hotden dkk., 2014) dan menggambarkan banyak tegakan pohon yang berada dalam kawasan tersebut (Triyadi dkk. 2014).

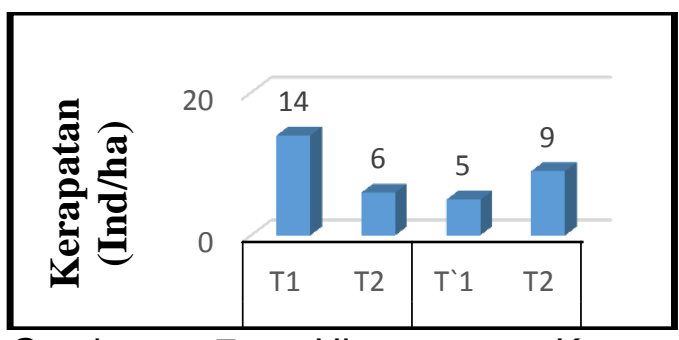

Gambar 7. Histogram Kerapatan Mangrove

Jenis Mangrove

\begin{tabular}{|c|c|c|c|c|c|c|}
\hline \multirow{2}{*}{ Jenis } & \multirow{2}{*}{ Famili } & \multirow{2}{*}{ Lokal } & \multicolumn{4}{|c|}{ Transek } \\
\hline & & & 1 & 2 & 3 & 4 \\
\hline $\begin{array}{c}\text { Sonner } \\
\text { atia } \\
\text { alba }\end{array}$ & $\begin{array}{c}\text { Sonnerati } \\
\text { aceae }\end{array}$ & $\begin{array}{c}\text { Posi - } \\
\text { Posi }\end{array}$ & * & * & * & * \\
\hline $\begin{array}{l}\text { Rhizop } \\
\text { hora } \\
\text { mucron } \\
\text { ata }\end{array}$ & $\begin{array}{c}\text { Rhizphora } \\
\text { ceae }\end{array}$ & Lalaro & & * & * & \\
\hline $\begin{array}{c}\text { Rhizop } \\
\text { hora } \\
\text { apiculat } \\
\text { a }\end{array}$ & $\begin{array}{l}\text { Rhizphora } \\
\text { ceae }\end{array}$ & $\begin{array}{l}\text { Makur } \\
\text { ung }\end{array}$ & & * & * & * \\
\hline
\end{tabular}

Jenis mangrove yang ditemukan pada 2 satsiun penelitian yaitu pada stasiun 1 transek 1 hanya ditemukan 1 jenis mangrove yaitu Sonneratia alba, dimana transek 1 ini berdasarkan matriks kesesuaian lahan wisata mangrove masuk ke kategori buruk. Transek 2 ditemukan 3 jenis mangrove yaitu Sonneratia alba, Rhizophora mucronata dan Rhizophora apiculate, berdasarkan matriks kesesuaian lahan wisata mangrove maka masuk pada

kategori cukup baik. Sedangkan pada stasiun 2 di transek 1 ditemukan 3 jenis mangrove yaitu Sonneratia alba, Rhizophora mucronata dan Rhizophora apiculate, berdasarkan matriks kesesuaian lahan wisata mangrove maka masuk pada kategori cukup baik. Pada transek 2 hanya ditemukan 2 jenis yaitu Sonneratia alba dan Rhizophora apiculata, berdasarkan matriks kesesuaian lahan wisata mangrove maka masuk pada kategori cukup buruk (Lampiran 5). Semakin banyak jenis mangrove maka pengunjung dapat mengetahui lebih banyak.

\section{Pasang Surut}

Pulau Bunaken memiliki pantai yang landai. Berdasarkan data sekunder BMKG Sulut tabel pasang surut pada bulan Desember 2018, pasang air laut tertinggi yaitu $6.4 \mathrm{~m}$ dan surut terendah $1.6 \mathrm{~m}$ dengan hasil $4.8 \mathrm{~m}$, maka berdsarkan matriks kesesuaian lahan wisata mangrove masuk pada kategori cukup buruk. Pasang surut sangat menentukan zonasi, pertumbuhan dan 
penyebaran kehidupan mangrove. Lama terjadinya pasang di kawasan mangrove dapat mempengaruhi perubahan salinitas air dimana salinitas meningkat pada saat pasang dan menurun pada saat air laut surut.

\section{Penilaian Kesesuaian Lahan Ekowisata Mangrove Pulau Bunaken}

\begin{tabular}{|l|c|c|c|c|c|c|}
\hline \multirow{2}{*}{ Parameter } & \multirow{2}{*}{ Bobot } & Analisa & \multicolumn{2}{|c|}{ Stasiun 1 } & \multicolumn{2}{|c|}{ Stasiun 2 } \\
\cline { 4 - 7 } & & Skor & Nilai & Skor & Nilai \\
\hline $\begin{array}{l}\text { Tutupan } \\
\text { kanopi }\end{array}$ & 5 & $41 \%$ & 1 & 5 & 1 & 5 \\
\hline $\begin{array}{l}\text { kerapatan } \\
\text { mangrove }\end{array}$ & 3 & $\begin{array}{c}10 \\
\text { ind/m2 }\end{array}$ & 3 & 9 & 2 & 6 \\
\hline $\begin{array}{l}\text { jenis } \\
\text { mangrove }\end{array}$ & 3 & 3 jenis & 2 & 6 & 2 & 6 \\
\hline $\begin{array}{l}\text { pasang } \\
\text { surut }\end{array}$ & 1 & $4.8 \mathrm{~m}$ & 1 & 1 & 1 & 1 \\
\hline Jumblah & & \multicolumn{5}{|c|}{$54 \%$} \\
\hline $\begin{array}{l}\text { Nilai } \\
\text { Kesesuaian }\end{array}$ & & \multicolumn{3}{|c|}{$58,33 \%$} & \multicolumn{2}{|c|}{$50 \%$} \\
\hline $\begin{array}{c}\text { Kategori } \\
\text { kesesuaian }\end{array}$ & \multicolumn{5}{|c|}{ Sesuai } \\
\cline { 3 - 7 }
\end{tabular}

Berdasarkan tabel diatas dapat disimpulkan bahwa indeks kesesuaian lahan mangrove pada Stasiun 1 adalah $21 \%$, Stasiun 2 adalah $18 \%$, untuk keseluruhan transek nilai yang di dapatkan adalah $54 \%$, nilai yang masuk pada kategori sesuai.

\section{KESIMPULAN DAN SARAN Kesimpulan}

Berdasarkan tujuan penelitian yang dilakukan memperoleh hasil yang dapat disimpulkan sebagai berikut :

1.Pulau Bunaken memiliki nilai struktur komunitas mangrove:

-Nilai kerapatan tertinggi yaitu pada stasiun 1 di transek 2 jenis S.alba 0.16 ind $/ \mathrm{m} 2$ relatifnya $88.89 \%$ dan nilai kerapatan terendah pada jenis $R$. mucronata dan R.apiculata $0.01 \mathrm{ind} / \mathrm{m} 2$ relatifnya $5.56 \%$ di transek 2 pada 1.00 relatifnya $100 \%$ dan frekuensi terendah pada stasiun 1 transek 2 jenis $R$, piculate yaitu 0.50 relatifnya 33.33 .stasiun 1

-Nilai frekuensi jenis tertinggi pada stasiun 1 di transek 1 jenis S.alba yaitu
-Nilai penutupan jenis tertinggi pada transek 2 stasun 1 jenis S. alba 10.26 nilai relatifnya $92.63 \%$. Sedangkan penutupan jenis terendah transek 3 jenisR. piculate 0.49 relatifnya $7.86 \%$

-Indeks Nilai Penting tertinggi yaitu pada stasiun 1 di transek 1 yaitu jenis S.alba 300 dan terendah pada stasiun 1 di transek 2 jenis R.mucronata 30.55

- Nilai keanekaragaman tertinggi pada transek 2, 0.43. Nilai indeks kemerataan (E) pada stasiun 1 di transek 1 yaitu 0 dan transek 20,39 . Sedangkan stasiun 2 pada transek 10 dan transek 20.51 .

2. Ditinjau dari Kepmen LH No. 201 Tahun 2004 tentang kriteria kerusakan mangrove, pada ke 2 stasiun termasuk pada kategori jarang dengan tutupan kanopinya $\leq 50 \%$.

3. Hasil keseluruhan kesesuaian lahan untuk wisata pantai kategori wisata mangrove Pulau Bunaken masuk pada kategori sesuai.

\section{Saran}

Dari hasil penelitian yang diperoleh maka sarannya perlu adanya penelitian yang lebih lanjut mengenai kesesuaian lahan ekowisata untuk dapat menggali potensi sumberdaya wisata Pulau Bunaken Timur serta tetap menjaga dan melestarikan hutan mangrove.

\section{DAFTAR PUSTAKA}

Abrar, M., Giyanto., Siringoringo, R.M., Edrus, I.N., Arbi, U.Y., Sihaloho,H.F.,Salatalohi, A dan Sutiadi. 2014. Laporan Monitoring (Baseline) Kesehatan Ekosistem Terumbu Karang dan Ekosistem Terkait Lainnya. Taman Wisata Perairan Pulau Pieh dan Laut di sekitarnya, Provinsi Sumatera Barat. Pusat Penelitian Oseanografi. Lembaga Ilmu Pengetahuan Indonesia. 57 Hal.

Agustini, N. Tri., Ta'aladin, $Z$ dan Purnama, D. 2016. Struktur Komunitas Mangrove di Desa Kahyapu Pulau Enggano. Program Studi IImu Kelautan Fakultas Pertanian Universitas Bengkulu, Bengkulu. EISSN:2527-5186 Jurnal 
Enggano Vol 1. No.1, April 2016:1931.

Anderson, M.C. 1964. Studies of the wood-land light climate in the photographic computation of light condition. Journal of Ecology. 52: 27-41.

Anthoni Annice., Joshian N.W Schaduw., dan Calvyn F.A Sondak. 2017. Persentase Tutupan dan Struktur Komunitas Mangrove Di Sepanjang Pesisir Taman Nasional Bunaken Bagian Utara. Jurnal Pesisir dan Laut Tropis. Vol 2 (1): 13-21

Bengen, D.G. 2003. Ekosistem dan Sumberdaya Pesisir dan Laut serta Pengelolaann Secara Terpadu dan Berkelanjutan. In: Koleksi Dokumen Proyek Pesisir 1997-2003

Bengen, D.G. 2004. Sinopsis Ekosistem dan Sumberdaya Pesisir dan Laut Serta Prinsip Pengelolaannya. Cetakan Ketiga. Bogor : Pusat Kajian Sumber Daya Pesisir dan Lautan, Institut Pertanian Bogor.

Bessie, M.D., Joshian. N. Schaduw., Emil Reppie., Markus. T. Lasut. 2013. Community Structure Of Mangrove At Marine Tourism Park Of Kupang Bay,

East Nusa Tenggara. Aquat Science \& Management. hal 3-9

(BTNB) Balai Taman Nasional Bunaken. 2010 . Rencana Pengelolaan Jangka Panjang Taman Nasional Bunaken Periode Tahun 1996-2021 ( Review ) Provinsi Sulawesi Utara. Manado : Balai Taman Nasional Bunaken. Kementrian Kelautan. Direjen Perlindungan Hutan dan Konservasi Alam.

Dharmawan, I.W.E. \& Pramudji. 2014. Panduan Monitoring Status Ekosistem Mangrove. COREMAPCTI. Pusat Penelitian Oseanografi.
Lembaga Ilmu Pengetahuan
Indonesia. 46 hal.

Damanik, Janianton dan Helmut $F$. Weber. 2006. Perencanaan Ekowisata Dari Teori Ke Aplikasi. Yogyakarta: Andi OffsetDirejen RLPS. 2002. Rehabilitas Lahan dan Perhutanan Sosial. Jakarta: Departemen Kehutanan

ITTO. 2014. Assessment On Biodiversity With Emphasize On Endangered Species In Betung Kerihun National Park, Jakarta.

Indriyanto. 2006. Ekologi Hutan. Jakarta: Penerbit Bumi Aksara.Korhonen, L., Korhonen, K.T., Rautiainen, $M$ \& Stenberg, P. 2006. Estimation of forest canopy cover: a comparison of field measurement techniques. SilvaFennica 40 (4) : 577-588.

Keputusan Menteri Negara Lingkungan Hidup No. 201 tahun 2004, tentang Kriteria Baku dan Pedoman Penentuan Kerusakan Mangrove.

Kustanti, A. 2011. Manajemen Hutan Mangrove . IPB Press. Bogor

Lahabu, Y., J.N.M. Schaduw., A.B. Windarto. 2015. Kondisi Ekologi Mangrove Di Pulau Mantehage Kecamatan Wori Kabupaten Minahasa Utara Provinsi Sulawesi Utara. Jurnal Pesisir dan Laut Tropis. Vol. I No. (1) : 41-50

LIPI, 2014. Kekinian Keanekaragaman Hayati Indonesia 2014. LIPI Pres, anggotalkapi. Pusat Penelitian Biologi.

Mangkay, S., N. Harahab., P. Bobby., dan Soemarno. 2012. Analisis strategis pengelolaan hutan mangrove berkelanjutan di Kecamatan Tatapaan, Minahasa Selatan, Indonesia. J-PAL. VOI.3 (1) :8-8.

Muhaerin, M. 2008. Kajian Sumberdaya Ekosistem Mangrove Untuk 
Pengelolaan Ekowisata Di Estuari Perancak, Jembrana, Bali. Departemen Manajemen Sumberdaya Perairan. Fakultas Perikanan Dan IIImu Kelautan. Institur Pertanian Bogor. Skripsi. 94 hal

Murdiyarso, D., Purbopuspito, J., Kauffman, J. B., Warren, M., Sasmito, S., Donato, Kurnianto, S. 2015. The potential of Indonesian mangrove forests for global climate change mitigation. Nature Climate Change. Vol.5, DOI: 10.1038/NCLIMATE2734.

Nybakken, J. W. 1992. Biologi Laut Suatu Pendekatan Biologis. PT Gramedia. Jakarta

Odum. E.P. 1972. Fundamental Ecology 3rd. Ed W.B. Sounders.

Pramudji. 2000. Dampak Perilaku Manusia Pada Ekosistem Hutan Mangrove Di Indonesia. Oseana (25) : 13-20

Rompas R. M. et al. 2008. Pengantar Ilmu Kelautan. Sekretariat Dewan Kelautan Indonesia. Jakarta

Raymond, G., H. Nurdin., dan Soemarno. 2010. Pengelolaan hutan mangrove berbasis masyarakat di Kecamatan Gending, Probolinggo. Jurnal agritek. Vol 18 No. 2 : 186187

Rusydi., Ihwan., Suaedin. 2015. Struktur dan Kepadatan Vegetasi Mangrove Di Teluk Kupang. Jurnal Segara. Vol 11 (2) : 147-157

Schaduw. N. W. Joshian. 2016. Kondisi Ekologi Mangrove Pulau Bunaken Kota Manado Provinsi Sulawesi Utara. Jurnal LPPM Bidang Sains dan Teknologi. Vol 3 No.2 : 64-74

Schaduw. N. W. 2018. Distribusi dan Karakteristik Kualitas Perairan Ekosistem Mangrove Pulau Kecil Taman Nasional Bunaken. Majala
Geografis Indonesia. Vol 32 (1): 40-49

Sofian A, Harahap dan Marsoedi.2012. Kondisi dan ManfaatLangsung EkosistemHutan Mangrove Desa Penunggul Kecamatan Nguling Kabupaten Pasuruan Jurnal ElHayah. Vol 2 No. 2 : 56-63

Subhan, M. 2014. Analisis tingkat kerusakan dan strategis pengelolaan mangrove $\mathrm{Di}$ Kawasan Suka Perikanan Gili Ranggo Teluk Seriwe Kabupaten Lombok Timur Nusa Tenggara Barat. (Tesis). Program Studi Lingkungan Program Pascasarjana Universitas Udayana. Denpasar.

Tuwo, A. 2011. Pengelolaan Ekowisata Pesisir dan Laut. Surabaya: Brilian Internasional. 412 hal.

Triyadi, E., Zulkifar A., Idris F. 2014. Analisis Kesesuaian Ekosistem Mangrove Untuk Pengembangan Ekowisata. Fakultas IImu Kelautan dan Perikanan. Universitas Maritim Raja Ali Haji.

Yulinda, F. 2007. Ekowisata Bahari Sebagai Alternatif Pemanfaatan Sumberdaya Pesisir Berbasis Konservasi. Makalah Seminar Sains 21 Febuari 2007. Departemen Manajemen Sumberdaya Perairan, FPIK. IPB. 